\title{
Parliamentary News
}

\section{(October 1985-March 1986: Part I)}

The House of Commons reassembled on 21 October 1985 after the Summer Recess. Parliament was prorogued and assembled to hear the Queen's Speech on 6 November 1985.

\section{Control of narcotics}

The Parliamentary Under-Secretary of State (Home Office), Mr Mellor, on 24 October reported on a recent visit to Pakistan where he held discussions with Government and other agencies regarding the control of narcotics. He published a Memorandum of Understanding between the Government of Pakistan and the UK which confirmed their commitment to engage in close co-operation to tackle the problem of unlawful production and trafficking in narcotics and the joint measures which they agreed to undertake to deal with it.

\section{European Court of Human Rights}

The Home Secretary confirmed that the Government has decided to renew, for a period of five years from January 1986, their acceptance of the right of individual petition to the European Commission of Human Rights and the jurisdiction of the European Court of Human Rights.

\section{Commission for Racial Equality}

On 21 October Mr Waddington (Home Office) gave the names of the present membership of the Commission. It includes Dr Farrukh Hashmi, Consultant Psychiatrist, Birmingham.

Prison medical officers (training)

In reply to a question (28 October) Mr David Mellor said that prison medical officers at establishments which receive direct committals from the courts are experienced in the recognition and treatment of the physical symptoms of drug dependency, and many have received psychiatric training or experience. All medical officers are encouraged, and are allowed opportunity, to attend external refresher and development courses relevant to this and other aspects of their work. Hospital officers, who work under medical direction, receive theoretical and practical instruction in the nursing care of drug dependence as part of their basic training.

\section{Access to personal files}

On 29 October Mr Archy Kirkwood MP was given leave to present a Bill to provide access for private individuals to information relating to themselves maintained by certain authorities, institutions and persons; to allow individuals to obtain copies of, and require corrections to be made to, such information; and to provide for the enforcement of these provisions. A Bill was read the First time and ordered to be read a Second time on the 30 October. The Bill embraces the principal public authorities providing services to the public and includes health authorities and individual doctors. Among the important exceptions built into the Bill include the provision that information will not be released when it is the opinion of a doctor that it could cause mental distress to a patient.

\section{Park Lane Hospital, Liverpool (Restricted patients)}

On 7 November 1985 the Home Secretary was criticised because, prior to a tribunal on a restricted patient $\mathrm{Mr}$ David Mellor, the Parliamentary Under Secretary (Home Office) revealed to the press his view that the patient concerned was not fit to be discharged. Mr Mellor was criticised but defended his actions on the basis that he had already expressed his opinion in the House of Commons and thus felt it proper to respond a journalist's question about that answer. Others felt that the rule of law was thereby interfered with.

\section{Commission for Racial Equality (Code of Practice)}

In an answer on 14 November $1985 \mathrm{Mr}$ Hayhoe (DHSS) confirmed that the Code of Practice on Race Relations was approved by the Government in March 1984 to come into effect on 1 April 1984. The Chairman of the Commission wrote to the chairmen of all health authorities in November 1983 drawing their attention to the Code of Practice and it is believed that they are all well aware of their responsibilities.

\section{Mental patients}

Mr Whitney (DHSS) said (19 November 1985) that in the course of the year 1984 there were a total of 16,019 compulsory admissions to mental illness and mental handicap hospital and units in England under the terms of the Mental Health Act 1983 and on 31 December 1984, 5,892 patients were detained under the Act. The yearly figure includes some patients admitted more than once.

\section{Community care}

On 20 November Mr Barney Hayhoe (DHSS) announced that the Government's response to the Report of the Social Services Committee on community care with special reference to adult mentally ill and mentally handicapped people had been published that day (Cmnd. 9674). The Government generally welcomed the support given by the Committee to the Government's policy on community care.

\section{Mentally ill and handicapped prisoners}

On 20 November the Home Secretary was asked for the 
present statistics and comparisons with each of the 10 preceding years. The number of inmates who in the opinion of prison medical officers are suffering from mental disorder of a nature or degree which would satisfy the criteria in the Mental Health Acts of 1959 and 1983 is shown in the following table. There was no census before 1977 and the latest available figures are for the 31 March 1985.

$\begin{array}{llll}\text { 30 June 1977 } & 769 & \text { 31 March 1982 } & 287 \\ \text { 30 June 1978 } & 581 & \text { 31 March 1983 } & 319 \\ \text { 30 June 1979 } & 557 & \text { 31 March 1984 } & 310 \\ \text { 30 June 1980 } & 457 & \text { 31 March 1985 } & 269\end{array}$

30 June $1981 \quad 320$

\section{Child abuse}

On 21 November Dr Norman Godman asked a number of questions of the Home Secretary and the Secretary of State for Scotland on statistics relating to child abuse. Tables are published in Weekly Hansard Issue No. 1362.

\section{Regional Secure Units}

On 2 December Mr Kilroy Silk repeated his customary question on the statistics relating to these units. In reply Mr Whitney (DHSS) gave a breakdown of the current figures indicating that 10 of the 14 NHS regions now have permanent regional secure units in operation, providing a total of $\mathbf{4 0 5}$ beds of which $\mathbf{2 9 8}$ are staffed and available. The latest information held centrally on interim secure units gives the position at 31 October 1984 and this indicates that 284 beds are available in interim units, 108 of these are in mental handicap hospitals.

\section{Care of the mentally ill}

On 4 December 1985 the House of Lords debated the needs of the mentally ill and mentally handicapped with a special reference to community care. Concern was expressed about the need to continue to support a sufficient number of beds for people who need in-patient care, the lack of necessary community care being made available in advance of a reduction in beds and concern expressed by members of the National Schizophrenia Fellowship at the lack of understanding of mental illness by some general practitioners, the lack of sympathy for families and their problems by some psychiatrists and a failure to appreciate that parents grow older and become less able to cope. A fourth matter for concern (in a speech by Lord Mottistone) was that so-called patient power may develop as strongly here as in other countries. The support apparently being given to this totally erroneous movement by MIND much concerned him. He regarded bodies such as the Campaign Against Psychiatric Oppression not only as misguided but also as evil. Lord Ennals emphasised 10 points he wished the Government to keep in mind. They included some already made by Lord Mottistone but also the need for a bridging fund during transition from hospital to local community care. He asked for a substantial increase in the housing investment programme to provide accommodation in the community for patients and he also asked the Government to remove disincentives such as rate capping and manpower targets on local government and health authorities. He asked for an agreed vision for a new service from professionals and others for the dissemination of models of good practice. He looked for a partnership between various administrative bodies and a full consumer participation in service planning and delivery. He requested that the invalid care allowance should now be extended to married and cohabiting women. Lord Winstanley considered that nowhere was the case more clearly summarised than at the very opening of the paper distributed by the Royal College of Psychiatrists, 'A highly influential and very important body'.

The full Debate can be found in House of Lords Weekly Hansard No. 1307.

\section{Regional health authorities}

On 11 December 1985 current membership of regional health authorities was published in a reply to a Parliamentary Question. The only psychiatric member of a regional health authority is Dr Julian Roberts (Yorkshire).

\section{Select Committees}

On 16 January $1986 \mathrm{Mr}$ Biffen, in reply to a series of questions, gave details of the work of the Parliamentary Select Committee of the House of Commons, including the attendance of Members, the number of reports produced and details of them, the names of specialist advisers and their cost. Other details were also given. The Social Services Committee (Chairman, Mrs Rence Short, MP) has appointed 25 specialist advisers since the establishment of Select Committees in 1979. They include previously Professor J. Wing and at the present time Professor J. Gunn, Dr J. MacKeith and Professor R. Bluglass.

\section{NHS (general managers)}

On 21 January Mr Barney Hayhoe (DHSS) gave details of the appointment of managers at regional, district and unit level. The backgrounds of those appointed were given. Of 14 regional managers appointed, one is a doctor; of 191 district general managers, 15 are doctors and of $\mathbf{4 0 0}$ unit general managers, 79 are doctors. Full details are given in Weekly Hansard Issue No. 1368, Cols. 134-135.

\section{Holloway Prison}

Mr Mellor (Home Office) said on 24 January that a site had been found and work is going ahead on planning new purpose-built accommodation to replace the $C .1$ unit at Holloway Prison. As recommended by the Project Committee advice is being sought from the DHSS.

\section{Social workers (training)}

In reply to a question (24 January 1986) Mr Whitney (DHSS) said that appropriate training in child care law and practice is essential for social workers and those qualifying under CCETSW courses. The Council is engaged in consultations about the present content of teaching and 
the availability of supervised practice in cases of child abuse with a view to establishing the possibilities for improvement in both qualifying and in-service courses. When it comes to applying the law in particular cases, it is for employing local authorities to ensure that legal guidance is available for social workers.

\section{Electroconvulsive Therapy}

On 27 January Mr Whitney (DHSS) replied to a question from Sir David Price on the extent of use of ECT for the treatment of depressive illness and manic depressive psychosis. He published a table indicating the number of courses of treatment given annually from 1979-84. They were as follows:

$\begin{array}{llll}1980 & 25441 & 1983 & 21350 \\ 1981 & 24407 & 1984 & 19850 \\ 1982 & 22578 & & \end{array}$

\section{Mental Health Act Commission}

On 28 January in reply to a question from $\mathrm{Mr}$ Harvey Proctor, MP, the Minister of Health said that he had no plans at present to meet the Chairman of the Mental Health Act Commission and if he did he would bear in mind a suggestion from Mr Proctor that there should be a clear investigation of the Commission's complaints procedure. This was followed by concern expressed by Ms Harriet Harman, MP that the Minister should set up an inquiry into the events leading to the death of a psychiatric social worker at Bexley Hospital who was murdered by a former client. Ms Harman asked the Minister to recognise that there is a number of seriously mentally ill people who, if they are discharged under the community care policies and do not receive the support and treatment that their illness requires will be a danger to themselves and to the community.

\section{Incest and Related Ofiences (Scotland) Bill}

The House of Lords considered the Committee Stage of this Bill on 28 and 29 January 1986. It would introduce changes to the law of incest in Scotland following recommendations of the Scottish Law Commission.

\section{Parliamentary Commissioner for NHS: Remit}

In the House of Lords (30 January) in reply to a question Baroness Trumpington said that the Government had considered carefully the question of extending the remit of the Parliamentary Commissioner for the NHS to include complaints involving clinical issues and judgments. They decided against it. In 1981 the Government introduced a special procedure to deal with such complaints based on a professional review of such cases by two independent consultants. The Government is currently reviewing that procedure with the relevant professional bodies but have no plans to consider the Health Service Commissioners powers in this context.

\section{Children and Young Persons (Amendment) Bill}

This Bill had a Second Reading on 31 January 1986. In introducing it Mr Denis Walters, MP explained the Bill's main provisions in detail. Clause 1 would require the consent of the juvenile court before a local authority could implement a recommendation to return a child 'in care' to the home where he or she was living before the Care Order was made. Secondly the Bill spells out the test which should be applied before a child is returned home-that is all the circumstances the child will face. Thirdly the Bill empowers and encourages the court to attach conditions to the return of the child.

The House then gave general consideration to the Bill in debate.

\section{Suicide in prison}

Lord Glenarthur (Home Office) said on 6 February that the Home Office Working Group on Suicides in Prison which had been established following the report of the Chief Inspector of Prisons published in September 1983 had completed its work and the Home Secretary was considering how to give early effect to the Working Group's conclusions.

\section{Medical education}

The Government's response to the Fifth Report of the Social Services Committee 1984-85 Session on medical education was published on the 13 February 1986 (Cmnd. 9701).

\section{Magistrates}

The Attorney General said (13 February 1986) that on the 1 January 1986 in England and Wales 16,133 men and 11,554 women were serving as active justices of the peace. The estimated average attendances at court sittings were between 35 and 40 half-day sittings a year.

\section{Dementia}

On 14 February 1986 Mr Whitney (DHSS) said that the main Government-funded body carrying out research into Alzheimer's Disease and senile dementia is the Medical Research Council from its annual grant-in-aid from the science Vote of the Department of Education and Science. The Department also spends some $f 12$ million a year on research into health and social services. At present three studies are being supported into the problems of the elderly mentally infirm including those with severe dementia at a cost of some $£ 140,000$ a year.

\section{Public expenditure}

On 20 February 1986 the House of Commons debated the White Paper on the Government's expenditure plans 1966-87 to 1988-89. Mrs Renée Short, Chairman of the Parliamentary Select Committee on Social Services, drew attention to the Committee's 1981 recommendations that there should be an increase in the number of consultant posts and a reduction in training posts. The Government accepted that recommendation and in 1985 the Committee 
again looked at the issue to check what progress had been made and found that the ratio of consultants to junior doctors had hardly changed. The Government replied to that follow-up report with agreement, stating 'there appears therefore to be an impasse'. To resolve the problem there is to be another review of the whole subject by the Government and the Joint Consultants Committee. She was concerned about the deterioration in services in a variety of areas if no action is taken soon.

\section{Day centres for the mentally ill}

In reply to a question (21 February 1986) Mr Whitney (DHSS) gave details in the form of a table of day centre places for mentally ill people in England as at 31 March 1985. The statistics refer to local authority day centres and places in centres provided by voluntary and other organisations. The details can be found in Hansard Issue No. 1372, columns 392-394.

\section{Special Hospitals (Management)}

In reply to a question in the House of Lords (25 February 1986) Baroness Trumpington (DHSS) said that when the term of appointment of the Rampton Hospital Review Board expires in June a permanent local board will be established by the Secretary of State which will be a special health authority and will be accountable to him. Experience of the Review Board at Rampton had shown that the hospital had clearly benefited and its image had also improved. The Board is chaired by a businessman and has members with relevant interests and experience who know the hospital well and can stand a little apart from the day to day business. It provides an intermediate tier between the hospital management team and the DHSS. The Board has been able to provide closer oversight of the hospital management team and strengthened its accountability. It has also introduced tighter mechanisms of financial control and has generally encouraged better management practices. Similar arrangements are also to be established at the other Special Hospitals, Broadmoor, Moss Side and Park Lane.

\section{Psychotherapy}

In reply to a question (4 March) Mr Whitney (DHSS) said that no discussions had taken place with the DHSS about the regulation of the practice of psychotherapy. It was for the professions themselves to resolve the various issues involved and to reach a concensus view before the question of statutory registration could be considered. Figures were not maintained routinely for allegations of malpractice by practitioners with respect to psychotherapy but no complaints were known of in the past year.

\section{Drug Trafiicking Offences Bill}

On 4 March this Bill had its Second Reading in the House of Lords.

ROBERT BLUGLASS

\section{Correspondence}

\section{The Health Advisory Service-A quango running wild?}

DeAR SIRS

The letter from Professor Goldberg and his colleagues of the University Hospital of South Manchester (Bulletin, February 1986, 10,36) struck chords in relation to the HAS visit to Northwick Park Hospital. We also felt that the HAS team had little comprehension of the limitations of psychiatric knowledge, adopted an inappropriately directive approach and failed to avoid taking partisan views.

Whereas the origins of the HAS system lay in justified public concern about inadequate or improper treatment of psychiatric patients in NHS hospitals our experience of the HAS visit suggests that the authority and scope of the Service now extend far beyond this remit. It has become a system whereby a small group of individuals attempt to impose particular views concerning psychiatric treatment and its organisation upon individual health districts. Because the scope of the HAS recommendations are so broad they cover many areas where evidence is extremely limited and what constitutes effective psychiatric treatment or organisation of services is subject to wide and genuine differences of opinion.

This problem simply was not recognised by our visiting committee. Awarded the cloak of HAS authority they succumbed to the temptation to lay down the law on a variety of questions including issues on which their own knowledge of practice and the development and costs of services in Harrow was circumscribed. Put simply much of the content of the report was no more than the opinion of individual HAS members, unsupported by evidence.

For example the visiting committee commented adversely upon outpatients without seeing a clinic, interviewing any member of staff who worked in one or any patient who attended one. The basis for their statement that communication about patients is poor was obscure as in our hospital a letter follows every outpatient visit. They felt free in their summary to state without qualification that the orientation of the majority of the consultant body has prevented the development of psychotherapeutic and social approaches to psychiatry' in spite of the fact that they were told during their visit of the extensive studies of the treatment and outcome of functional psychoses, their social cost and possible social precipitants conducted at Northwick Park.

By contrast several aspects of the report indicated 